\title{
Studies on the Total Synthesis of Amphidinolide O (II): A Stereoselective Synthesis of C1-C11 Fragment
}

\author{
Mi-Yeon Jang, Jong-Woo Kim, and Duck-Hyung Lee* \\ Department of Chemistry, Sogang University, Seoul 121-742, Korea. *E-mail: dhlee@ccs.sogang.ac.kr \\ Received June 18, 2005
}

Key Words : Amphidinolide O, Cytotoxic macrolide, Stereoselective synthesis, 1,5-anti-Selective aldol reaction, 1,3-anti-Selective reduction of $\beta$-hydroxy ketone

The amphidinolides were isolated from the marine dinoflagellate Amphidinium sp., which produces a host of secondary metabolites endowed with potent cytotoxicity against various cancer cell lines. Amphidinolide O (1) displayed potent in vitro cytotoxicity against L1210 marine leukemia cells and human epidermoid carcinoma $\mathrm{KB}$ cells with 1.7 and $3.6 \mu \mathrm{g} / \mathrm{mL}$ of IC50s, respectively. ${ }^{1}$ In addition to our recent reports ${ }^{2}$ regarding to the synthesis of $\mathrm{C} 12-\mathrm{C} 17$ and C3-C11 fragments of amphidinolide O (1), we describe herein a new route to diastereoselective synthesis of C1-C11 fragment of $\mathbf{1}$.

The retrosynthetic analysis of $\mathbf{1}$ led to the C1-C11 fragment $\mathbf{2}$ and C12-C17 fragment $\mathbf{3}$ (Scheme 1). The hemiketal 2 was expected from acyclic precursor 4 which, in turn, would be derived by diastereoselective aldol reaction between ketone $\mathbf{5}$ and aldehyde $\mathbf{6}$.

The C1-C6 fragment 8 (equivalent to 5 in scheme 1) was prepared as summarized below (Scheme 2). Enolization of carboximide 7 with $\mathrm{Bu}_{2} \mathrm{BOTf}$ and $\mathrm{EtN}(i-\mathrm{Pr})_{2}$ was followed by reaction with aldehyde to provide the $s y n$-aldol product in

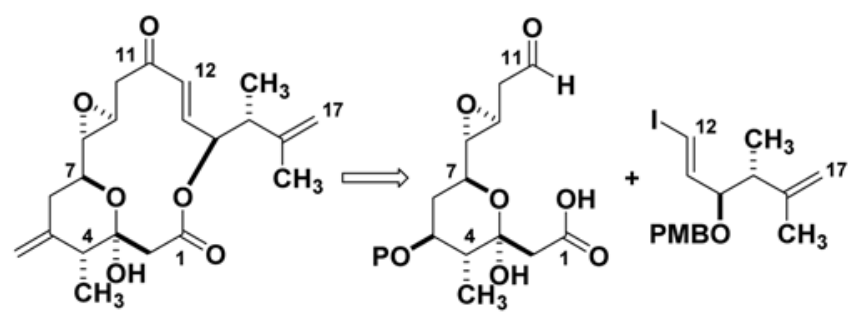

Amphidinolide $\mathrm{O}(\mathbf{1})$

2

3

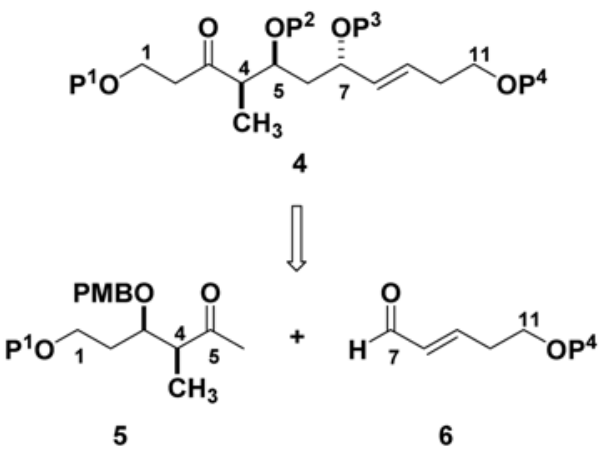

Scheme 1. Retrosynthesis of Amphidinolide O (1).

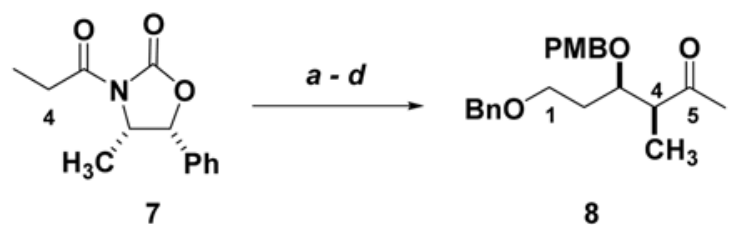

Scheme 2. Synthesis of C1-C6 fragment (8). (a) $\mathrm{Bu}_{2} \mathrm{BOTf}, \mathrm{EtN}(i-$ $\mathrm{Pr})_{2}, \mathrm{CH}_{2} \mathrm{Cl}_{2},-20^{\circ} \mathrm{C}, 20 \mathrm{~min} ; \mathrm{BnO}-\left(\mathrm{CH}_{2}\right)_{2} \mathrm{CHO},-78{ }^{\circ} \mathrm{C}, 1 \mathrm{~h}, 86 \%$; (b) $\mathrm{MeN}(\mathrm{OMe}) \mathrm{H}-\mathrm{HCl}, \mathrm{AlMe}_{3}$, THF, $-10{ }^{\circ} \mathrm{C}$ to rt, $3 \mathrm{~h}, 91 \%$; (c) $\mathrm{CCl}_{3} \mathrm{C}\left(4-\mathrm{MeO}-\mathrm{PhCH}_{2}\right)=\mathrm{NH}$, TsOH, $\mathrm{CH}_{2} \mathrm{Cl}_{2}, \mathrm{rt}, 2 \mathrm{~d}, 75 \%$; (d) $\mathrm{MeMgCl}, \mathrm{THF}, 0^{\circ} \mathrm{C}, 1 \mathrm{~h}, 85 \%$.

$86 \%$ yield $\left(\mathrm{ds}=>97: 3\right.$ by ${ }^{1} \mathrm{H}$ NMR analysis) (Scheme 2$){ }^{3}$ The aldol product was treated with $N, O$-dimethylhydroxylamine hydrochloride and $\mathrm{Al}(\mathrm{Me})_{3}$ to provide the Weinreb amide in $91 \%$ yield. ${ }^{4}$ The free hydroxyl group was protected as PMB ether, and finally Weinreb amide was converted to ketone 8 in $85 \%$ yield by reaction with $\mathrm{MeMgCl}$.

Synthesis of C7-C11 fragment $\mathbf{1 0}$ (equivalent to $\mathbf{6}$ in scheme 1) was completed via 5-step sequences (Scheme 3 ). Monoprotection of propane-1,3-diol (9), ${ }^{5}$ Swern oxidation of the remaining alcohol to aldehyde, and Wittig-olefination was undertaken to give $\alpha, \beta$-unsaturated ester, ${ }^{6}$ which was subsequently reduced by DIBAL and oxidized to provide the C7-C11 fragment 10, another key intermediate in the next aldol reaction.

Aldol-reactions of fragments $\mathbf{8}$ and $\mathbf{1 0}$ were investigated with four chiral boron reagents ${ }^{7}$ in ether at $-78{ }^{\circ} \mathrm{C}$ (Scheme 4 ), and the use of chlorodicyclohexylborane provided the desired product with the best diastereoselectivity (11a : 11b $=67: 33)$ in $61 \%$ (11a) and 30\% (11b) yield, respectively. Hydroxyl group-directed 1,3-anti reduction of either 11a or $\mathbf{1 1 b}$ with $\mathrm{NaBH}(\mathrm{OAc})_{3}$ provided the $5,7-$ anti $\operatorname{diol} \mathbf{1 2} \mathbf{a}$ or $\mathbf{1 2} \mathbf{b}$ in $91 \%$ yield.

The $(5 R, 7 S)$-isomer 12a was treated with 2,2-dimethoxypropane in the presence of PPTS (Scheme 5). The PMB-

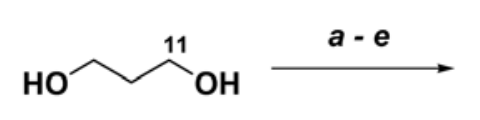

9

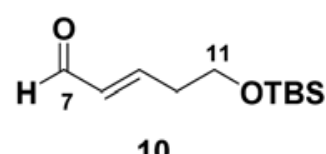

10
Scheme 3. Synthesis of C7-C11 fragment (10). (a) $\mathrm{TBSCl}$, imidazole, $\mathrm{CH}_{2} \mathrm{Cl}_{2}$, rt, $3 \mathrm{~d}, 87 \%$; (b) DMSO, $(\mathrm{COCl})_{2}, \mathrm{Et}_{3} \mathrm{~N}$, $\mathrm{CH}_{2} \mathrm{Cl}_{2},-78{ }^{\circ} \mathrm{C}, 1.5 \mathrm{~h}, 100 \%$; (c) $\mathrm{Ph}_{3} \mathrm{PCHCO}_{2} \mathrm{Et}$, benzene, $45^{\circ} \mathrm{C}, 1$ h, 89\%; (d) DIBAL, $\mathrm{CH}_{2} \mathrm{Cl}_{2},-78^{\circ} \mathrm{C}, 30 \mathrm{~min} ., 91 \%$; (e) DMSO, $(\mathrm{COCl})_{2}, \mathrm{Et}_{3} \mathrm{~N}, \mathrm{CH}_{2} \mathrm{Cl}_{2},-78^{\circ} \mathrm{C}, 1.5 \mathrm{~h}, 100 \%$. 
<smiles>CCOC(CCOCc1ccccc1)C(C)C(C)=O</smiles><smiles>CCOCCC=CC=O</smiles>

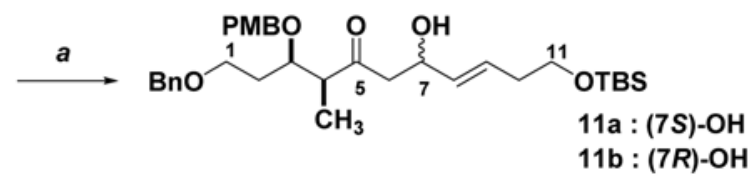

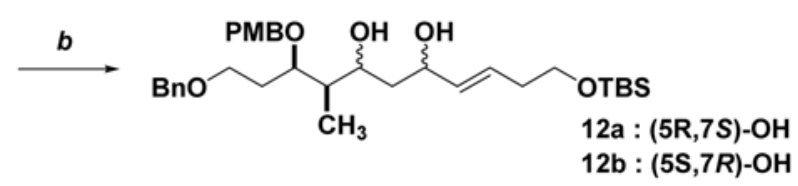

Scheme 4. Synthesis of 12a/12b. (a) $\operatorname{EtN}(i-\mathrm{Pr})_{2},(c-\mathrm{Hex})_{2} \mathrm{BCl}$, $\mathrm{Et}_{2} \mathrm{O},-78{ }^{\circ} \mathrm{C}, 1.5 \mathrm{~h}, 93 \%$; (b) $\mathrm{Me}_{4} \mathrm{NB}(\mathrm{OAc})_{3} \mathrm{H}, \mathrm{CH}_{3} \mathrm{CN} / \mathrm{AcOH}(1$ : 1), $-20^{\circ} \mathrm{C}, 2 \mathrm{~d}, 91 \%$.

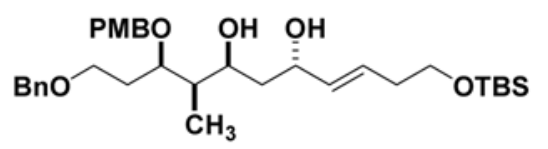

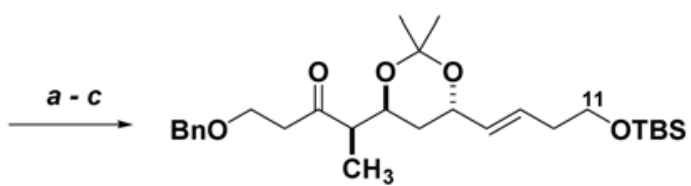
13

Scheme 5. Synthesis of C1-C11 fragment (13). (a) 2,2dimethoxypropane, PPTS(cat), $\mathrm{CH}_{2} \mathrm{Cl}_{2}, \mathrm{rt}, 1 \mathrm{~h}, 85 \%$; (b) DDQ, $\mathrm{CH}_{2} \mathrm{Cl}_{2} / \mathrm{H}_{2} \mathrm{O}$ (10 : 1), rt, 1 h, $72 \%$; (c) DMP, $\mathrm{CH}_{2} \mathrm{Cl}_{2}$, pyridine, rt, $40 \mathrm{~min}, 90 \%$

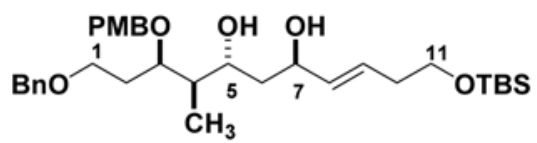
$12 b$

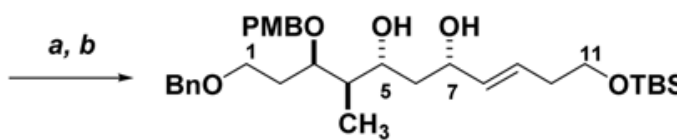

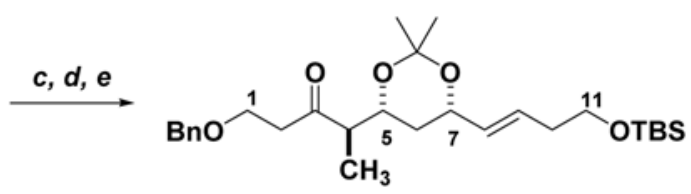

Scheme 6. Synthesis of C1-C11 fragment (15). (a) $\mathrm{MnO}_{2}, \mathrm{Et}_{2} \mathrm{O}$, rt, $2 \mathrm{~d}, 50 \%$; (b) DIBAL, $\mathrm{CH}_{2} \mathrm{Cl}_{2},-78^{\circ} \mathrm{C}, 30 \mathrm{~min}$., $90 \%$; (c) 2,2dimethoxypropane, PPTS(cat), $\mathrm{CH}_{2} \mathrm{Cl}_{2}, \mathrm{rt}, 1 \mathrm{~h}, 90 \%$; (d) DDQ, $\mathrm{CH}_{2} \mathrm{Cl}_{2} / \mathrm{H}_{2} \mathrm{O}$ (10:1), rt, $1 \mathrm{~h}, 72 \%$; (e) DMP, $\mathrm{CH}_{2} \mathrm{Cl}_{2}$, pyridine, rt, $40 \mathrm{~min}, 90 \%$.

protecting group was cleaved under standard reaction condition, ${ }^{8}$ and the free hydroxyl group was oxidized with Dess-Martin reagent to give the ketone 13. ${ }^{9}$ However, intramolecular cyclization of acetonide 13, a crucial step toward the total synthesis of amphidinolide O (1), under various acidic conditions resulted in the decomposition of $\mathbf{1 3}$ at $-78{ }^{\circ} \mathrm{C}$ without any indication for the presence of the

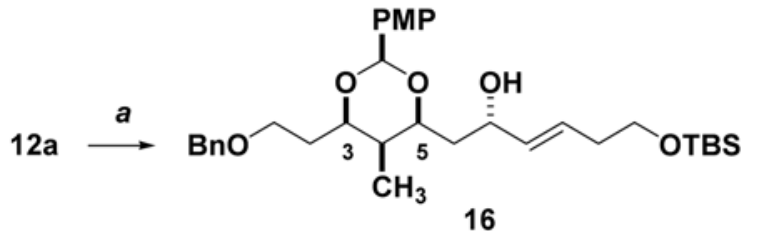

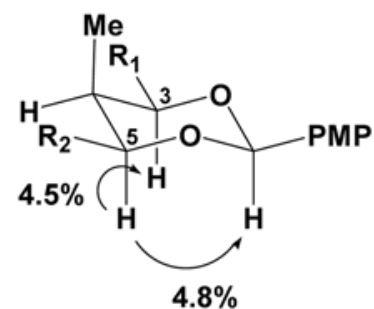

Scheme 7. Determination of relative stereochemistry of 12a. (a) DDQ, $\mathrm{CH}_{2} \mathrm{Cl}_{2}, 0{ }^{\circ} \mathrm{C}$ to rt, $1 \mathrm{~h}, 65 \%$.

desired tetrahydropyran ring.

The minor $(5 S, 7 R)$-isomer $\mathbf{1 2 b}$ was oxidized with manganese dioxide and the ketone was reduced with DIBAL to yield diol 14 (Scheme 6). The conversion of $\mathbf{1 4}$ into acetonide 15 was completed by the method in scheme 5 . However, the same result was obtained from the intramolecular cyclization of acetonide $\mathbf{1 5}$.

The relative stereochemistry of 12a was determined unambiguously from ${ }^{1} \mathrm{H}$ NOE spectroscopy of the acetonide 16, which was prepared via deprotection of PMB ether of 12a by DDQ and in situ cyclization (Scheme 7).

In summary, two ketones $\mathbf{1 3}$ and $\mathbf{1 5}$, the $\mathrm{C} 1-\mathrm{C} 11$ fragment of Amphidinolide O (1), were prepared stereoselectively via 14 and 16 step sequences in $8.7 \%$ and $2.0 \%$ overall yield, respectively.

Acknowledgement. This research was assisted financially by Korea Science and Engineering Foundation (R01-2000000-00048-0).

\section{References}

1. Ishibashi, M.; Takahashi, M.; kobayashi, J. J. Org. Chem. 1995, 60, 6022-6066.

2. (a) Pang, J. H.; Lee, D. H. Bull. Korean Chem. Soc. 2002, 23, 1173-1176. (b) Pang, J. H.; Ham, Y. J.; Lee, D. H. Bull. Korean Chem. Soc. 2003, 24, 891-892.

3. (a) Mapp, A. K.; Heathcock, C. H. J. Org. Chem. 1999, 64, $23-27$. (b) Evans, D. A.; Kaldor, S. W.; Jones, T. K.; Cardy, J.; Stout, T. J. J. Am. Chem. Soc. 1990, 112, 7001-7032.

4. Jones, T. K.; Reamer, R. A.; Desmond, R.; Mills, S. G. J. Am Chem. Soc. 1990, 112, 2998-3017.

5. (a) Urbanek, R. A.; Sabes, S. F.; Forsyth, C. J. J. Am. Chem. Soc 1998, 120, 2523-2533. (b) Chen, S.-M. L.; Schaub, R. E.; Grudzinskas, C. V. J. Org. Chem. 1978, 43, 3450-3454.

6. Nicolaou, K. C.; Webber, S. E. Synthesis 1986, 453-462.

7. $\mathrm{Bu}_{2} \mathrm{BOTf}(\mathrm{ds}=58: 42,93 \%$ yield $) ;(+)-\mathrm{DIPCl}(\mathrm{ds}=45: 55,85 \%$ yield); (-)-DIPCl (ds = $55: 45,85 \%$ yield $) ;(n-\mathrm{Ch})_{2} \mathrm{BCl}(\mathrm{ds}=67$ : $33,91 \%$ yield).

8. Liu, X.; Peter, H.; Seeberger, P. H. Chem. Comm. 2004, 15, 17081709.

9. Dess, D. B.; Matin, J. C. J. Org. Chem. 1983, 48, 4155-4156. 